\title{
SUSTAINABLE HOTEL STRATEGY EXECUTION: A REVIEW AND WAY FORWARD
}

\author{
G.H. Migale ${ }^{1,2 * \#}$, J.E. Stimie ${ }^{1}$ \& A.C. Brent ${ }^{1,3,4}$
}

\section{ARTICLE INFO}

\section{Article details}

Submitted by authors 1 Aug 2018

Accepted for publication 15 Nov 2019

Available online 12 Dec 2019

\section{Contact details}

Corresponding author

hmigale@udm.ac.mu

\section{Author affiliations}

1 Department of Industrial Engineering, Stellenbosch University, South Africa

2 Department of Electromechanical and Automation Engineering, Faculty of Sustainable Development and Engineering, Université des Mascareignes, Mauritius

3 Centre for Renewable and Sustainable Energy Studies, Stellenbosch University, South Africa

4 Sustainable Energy Systems, Engineering and Computer Science, Victoria University of Wellington, New Zealand
ABSTRACT

Tourism, the third largest industry in the world, is worth US\$ 1.4 trillion, and represents 10 per cent of the world's GDP. Tourism is also responsible for five per cent of the world's carbon dioxide emissions, of which hotels and other types of accommodation account for one per cent. In this context, a sustainable hotel strategy execution is essential for maintaining and improving our planet's socio-economic and ecological balance. This systematic review lays the foundation for the development of a sustainable hotel strategy decision and execution support tool. Systems thinking and system dynamics allow the modelling of the interdependent elements of a complex hotel system, followed by a scenario simulation for proper strategy-analysis and strategy-decision. The execution of the chosen strategy can then be compared with the expected results. With a view to appraising the potential development of such a sustainable hotel strategy execution model for any tourism destination, a systematic literature review was carried out on existing sustainable strategy execution models and tools, as well as the existing use of systems thinking and system dynamics in the tourism and hotel sector.

\section{OPSOMMING}

Toerisme, die derde grootste industrie ter wêreld, is $\$ 1.4$ biljoen werd en verteenwoordig 10 per sent van die wêreld se BBP. Toerisme is ook verantwoordelik vir vyf per sent van die wêreld se koolstofdioksiedemissies, waarvan hotelle en ander tipes akkommodasie verantwoordelik is vir een persent. Binne hierdie konteks is die implementering van volhoubare hotelstrategieë noodsaaklik vir die handhawing en verbetering van ons planeet se sosio-ekonomiese en ekologiese balans. Hierdie sistematiese oorsig bied die grondslag vir die ontwikkeling van 'n volhoubare hotelstrategiebesluit en uitvoeringsondersteuningsinstrument. Stelsel denke en stelsel dinamika laat die modellering van die interafhanklike elemente van 'n komplekse hotel stelsel toe, gevolg deur scenario simulasie vir behoorlike strategie-analise en -besluitneming. Die uitvoering van die gekose strategie kan dan vergelyk word met die verwagte resultate. Met die oog om die potensiële ontwikkeling van so 'n volhoubare hotelstrategieuitvoeringsmodel vir enige toeristebestemming te evalueer, is ' $\mathrm{n}$ sistematiese literatuuroorsig uitgevoer bestaande uit volhoubare strategie-uitvoeringsmodelle en gereedskap, sowel as die bestaande gebruik van stelsel-denke en stelsel dinamika in die toerisme en hotelle sektor.

\section{INTRODUCTION}

International tourism is a fast-growing industry. In 2016, according to the World Tourism Organisation (UNWTO), it ranked third in the world-wide export category, with "1,235 million 
international tourist arrivals, 7\% of world's exports representing a value of US\$ 1.4 trillion, $10 \%$ of the world's Gross Domestic Product (GDP), an employment of 1 in 10 jobs, and an expectation of 1.8 billion international tourist arrivals by 2030" [1,2]. A report of Hotel Energy Solutions (HES) [3] evaluated that, in 2011, the world's number of hotel rooms amounted to around 10 million, and noted that "tourism is responsible for $5 \%$ of the world's carbon dioxide emissions, out of which hotels and other types of accommodation account for 1\%". The sustainability of this rapidly-growing industry is of major importance, and the operations of the tourism industry and associated hotel sector need to be considered holistically. From the UNWTO definition of sustainable tourism [4], 'sustainable hotel' can be defined as a "hotel that takes full account of its current and future economic, social and environmental impacts, addressing the needs of its customers, the hotel sector within the tourism industry, the environment and host communities". Thus the complex strategic and operational interactions of hotels need to be analysed within their larger socio-ecological context. The use of systems thinking (ST) enables an analysis of the whole complex system with all its interdependent components [5]. Furthermore, system dynamics (SD) modelling and simulation can be carried out to reveal inconsistencies in the human limited thinking process [6]. It is thus proposed that incorporating sustainability and a systems approach may improve strategy execution in the hotel sector.

Stimie and Vlok [7] suggest that effective strategy execution (SE) involves the continuous critical evaluation and adjustment by an organisation regarding "the applicability of its organisational design and management systems" and "the readiness of its interpersonal processes" to achieve set strategic objectives. The development of a sustainable hotel strategy execution (SHSE) model using ST and SD will allow detailed analyses, prior to decision-taking and -execution, and therefore favour longterm effectiveness in the three dimensions of sustainable development: economic, social, and environmental [8]. ST and SD will enable a better understanding of the SE concerns of a sustainable hotel. This new model will improve the selection of appropriate strategies through scenario analyses. Moreover, monitoring and control will be eased during the execution of the chosen strategy, as SD will allow comparison between chosen strategic objectives and ongoing results. In fact, the use of ST and SD will facilitate effective SE, leading to improved hotel competitiveness and contributing to tourism sustainability goals.

\subsection{Objective of this paper}

This paper reviews the existing contemporary literature in SHSE in the international tourism industry. The objective is to appraise the potential development of a SHSE model using ST and SD.

\subsection{Overview of the remaining sections}

Section 2 describes the methodology used to review the contemporary publications, and presents a number of selected peer-reviewed documents. The chosen main themes and sub-themes are also elaborated. In section 3, the selected documents are critically analysed and discussed. Finally, in section 4 , the main findings are summarised and recommendations are presented.

\section{LITERATURE REVIEW METHODOLOGY AND RESULTS}

The first step was an analysis of the international tourism industry and associated hotel sector through online publications of the UNWTO and the International Hotel and Restaurant Association (IHRA). A systematic online literature review was then carried out on the existing contemporary research about how sustainable hotel strategies are being developed and executed in various countries around the world. A further review was also done on the use of ST and SD in hotels and tourism globally.

The online review included peer-reviewed journal papers, conference proceedings and papers, as well as master's dissertations and doctoral theses. Literature databases (Google Scholar, Scopus, and Academic Search Premier-EBSCOhost), together with specialised journal papers on hotels (International Journal of Tourism and Hospitality Research, Cornell School of Hotel Administration) and system dynamics (International Society for the Systems Sciences [ISSS] and System Dynamics Review [SDR]), were reviewed. The search used the keywords provided in Table 1. 
Table 1: List of keywords used for the search

\begin{tabular}{|c|c|}
\hline Keywords & Search location \\
\hline $\begin{array}{ll}\text { - } & \text { Sustainable+Hotel } \\
\text { - } & \text { Sustainable strategy execution+Hotel } \\
\text { - } & \text { Sustainable strategy implementation+Hotel } \\
\text { - } & \text { Systems thinking+modelling+hotels } \\
\text { - } & \text { Systems thinking+hotels } \\
\text { - } & \text { System dynamics+hotels } \\
\text { - } & \text { Systems thinking+ sustainable development } \\
\text { - } & \text { System dynamics+sustainable development } \\
\text { - } & \text { System dynamics+sustainability } \\
\text { - } & \text { Mechanism to evaluate the sustainable } \\
\text { - } \quad \text { strategy assessment of hotels } \\
\text { - } \quad \text { Hotel carbon footprint }\end{array}$ & $\begin{array}{l}\text { Google Scholar, followed by search in respective } \\
\text { journals }\end{array}$ \\
\hline $\begin{array}{ll} & \text { System dynamics+hotels } \\
\text { - } & \text { Sustainable+hotels+review } \\
\text { - } & \text { Hotel carbon footprint }\end{array}$ & Scopus \\
\hline $\begin{array}{ll}- & \text { System dynamics+hotels } \\
- & \text { Sustainable+hotels+review }\end{array}$ & Academic Search Premier-EBSCOhost \\
\hline $\begin{array}{ll}- & \text { System dynamics } \\
- & \text { Sustainable strategy execution }\end{array}$ & $\begin{array}{l}\text { International Journal of Tourism and Hospitality } \\
\text { Research }\end{array}$ \\
\hline $\begin{array}{ll}- & \text { System dynamics+hotels } \\
\text { - } & \text { System dynamics }\end{array}$ & Cornell School of Hotel Administration website \\
\hline - $\quad$ System dynamics & $\begin{array}{l}\text { Cornell Hotel and Restaurant Administration in } \\
\text { Academic One File from Stellenbosch University } \\
\text { Library }\end{array}$ \\
\hline - $\quad$ Hotels & $\begin{array}{l}\text { Journal of the International Society for the Systems } \\
\text { Sciences (ISSS) }\end{array}$ \\
\hline - Hotels & System Dynamics Review \\
\hline
\end{tabular}

This systematic online literature review led to a pre-selection of over 200 documents. The publication name for each identified study was noted, and the tourism destination (country or region) and/or context of the publication were studied. Recurrent main topics in the identified papers were used to determine the main themes $\left(M T_{i}, i=1, \ldots, 3\right)$ in Table 2 , while the idea, analysis, and/or implied assessment in these papers were used to establish the sub-themes $\left(\mathrm{ST}_{j}, j=1, \ldots, 3\right)$ in Table 3.

Sixty-eight of the pre-selected publications were submitted to further analysis so as to narrow the search to the most recent publications pertaining to the present work. These 68 publications were chosen on their capacity to provide a thorough understanding of the status of research in SHSE, as well as the present use of ST and SD in hotels and in the tourism industry. These selected papers were grouped under main themes and sub-themes.

Table 2 shows, in brackets, the number of selected publications per main theme.

Table 2: List of main themes

\begin{tabular}{|l|l|}
\hline \multicolumn{2}{|c|}{ Main themes } \\
\hline$M T_{1}$ & Existing worldwide research on hotel sustainability analyses and practice (48) \\
\hline$M T_{2}$ & $\begin{array}{l}\text { Existing worldwide research on strategy execution and general strategy approaches in } \\
\text { hotels (7) }\end{array}$ \\
\hline$M T_{3}$ & Existing worldwide ST and SD tools in tourism and hotels (12) \\
\hline
\end{tabular}

In Table 3, the number of papers related to each sub-theme is given in brackets. It is to be noted that one paper may highlight several ideas, analyses, and/or implied assessments, and so can relate to multiple sub-themes. 
Table 3: List of sub-themes

\begin{tabular}{|c|c|c|c|c|c|}
\hline \multicolumn{2}{|r|}{ Sub-theme $1\left(\mathrm{ST}_{1}\right)$} & \multicolumn{2}{|r|}{ Sub-theme $2\left(\mathrm{ST}_{2}\right)$} & \multicolumn{2}{|r|}{ Sub-theme $3\left(\mathrm{ST}_{3}\right)$} \\
\hline 1 & Hotel (58) & 1 & $\begin{array}{l}\text { Sustainability or } \\
\text { sustainable } \\
\text { development (58) }\end{array}$ & 1 & $\begin{array}{l}\text { Perceptions: Customers, employers and } \\
\text { employees (15) }\end{array}$ \\
\hline 2 & Tourism (12) & 2 & $\begin{array}{l}\text { Marketing, including } \\
\text { customer } \\
\text { relationship } \\
\text { management (5) }\end{array}$ & 2 & $\begin{array}{l}\text { Environment: Energy management system } \\
\text { (EMS) ISO } 14000 \text {, green approaches, eco- } \\
\text { certification, life cycle assessment (36) }\end{array}$ \\
\hline 3 & $\begin{array}{l}\text { Tourism enterprises } \\
\text { (including hotels) } \\
\text { (52) }\end{array}$ & 3 & $\begin{array}{l}\text { Strategy } \\
\text { formulation, } \\
\text { execution, and } \\
\text { evaluation (19) }\end{array}$ & 3 & $\begin{array}{l}\text { Social: Corporate social responsibility } \\
\text { (CSR), employee and/or community } \\
\text { participation and empowerment (1) }\end{array}$ \\
\hline 4 & $\begin{array}{l}\text { Country and/or } \\
\text { region and/or city } \\
(55)\end{array}$ & 4 & $\begin{array}{l}\text { Systems thinking and } \\
\text { system dynamics } \\
\text { (12) }\end{array}$ & 4 & $\begin{array}{l}\text { Performance measurement: Strategic } \\
\text { performance measurement, } \\
\text { benchmarking, balanced score board, } \\
\text { performance indicators, SWOT (20) }\end{array}$ \\
\hline 5 & $\begin{array}{l}\text { International or } \\
\text { global (4) }\end{array}$ & & & 5 & $\begin{array}{l}\text { Economic: Financial performance, } \\
\text { profitability (7) }\end{array}$ \\
\hline 6 & $\begin{array}{l}\text { Enterprises } \\
\text { (including tourism } \\
\text { enterprises) (52) }\end{array}$ & & & 6 & $\begin{array}{l}\text { Economic/social/environment, triple } \\
\text { bottom line (17) }\end{array}$ \\
\hline 7 & Building (2) & & & 7 & $\begin{array}{l}\text { Information technology and connectivity } \\
(2)\end{array}$ \\
\hline g & $\begin{array}{l}\text { General } \\
\text { applications (2) }\end{array}$ & & & 8 & $\begin{array}{l}\text { Resource use and efficiency: Energy, } \\
\text { water and others ( } 30)\end{array}$ \\
\hline & & & & 9 & Reporting (5) \\
\hline & & & & 10 & Renewable energy (10) \\
\hline & & & & 11 & Model (13) \\
\hline & & & & 12 & $\begin{array}{l}\text { Scenario planning and analysis, simulation } \\
\text { (12) }\end{array}$ \\
\hline & & & & 13 & New lifestyle $(0)$ \\
\hline & & & & 14 & $\begin{array}{l}\text { Policy preparation and implementation, } \\
\text { theoretical framework for stakeholder } \\
\text { involvement }(25)\end{array}$ \\
\hline & & & & 15 & $\begin{array}{l}\text { Quality management systems including } \\
\text { ISO } 9000 \text { and total quality management } \\
\text { (1) }\end{array}$ \\
\hline & & & & 16 & Certification (8) \\
\hline & & & & 17 & Supply chain (0) \\
\hline & & & & 18 & Competitive advantage (47) \\
\hline & & & & 19 & Learning organization (8) \\
\hline & & & & 20 & Country destination attractiveness (9) \\
\hline & & & & 21 & Education (2) \\
\hline & & & & 22 & Heritage preservation (7) \\
\hline
\end{tabular}

The group categories illustrated in Figures 1 and 2 give an overview of the main research interests in the field of SHSE. 


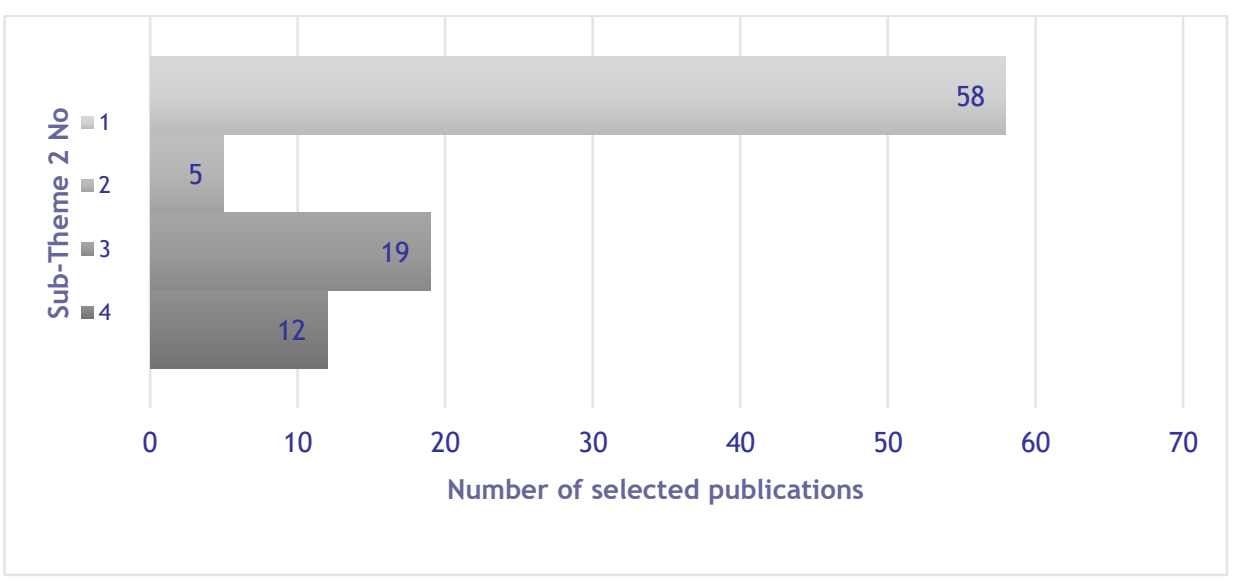

Figure 1: Number of selected publications per sub-theme

Figure 1 shows that a majority of the selected research involves the concept of sustainability, followed by strategy formulation, execution and evaluation, and ST and SD.

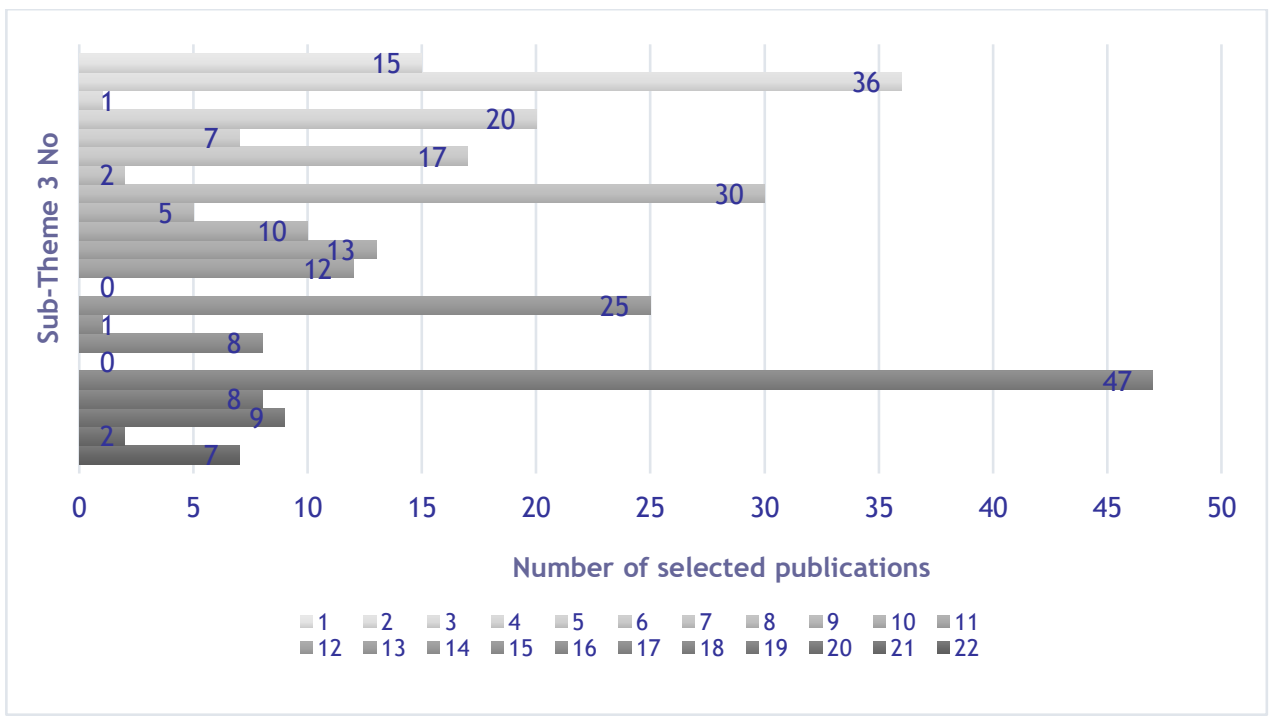

Figure 2: Number of selected publications per sub-theme 3

Figure 2 presents the main research concerns under the following categories: competitive advantage, environment, resource efficient use, and policy.

In this section, the literature review's methodology led to the identification of 68 contemporary publications, which jointly provide a detailed overview of the status of research in the considered field, while the results highlight the present concerns of hotel and tourism stakeholders.

\section{ANALYSIS AND DISCUSSION}

A critical analysis and discussion of the chosen literature is performed according to the main themes' classification, and knowledge gaps are identified accordingly.

\subsection{Existing worldwide research on hotel sustainability analyses and practices}

This sub-section reveals that hotel sustainability is an issue in most countries. However, the focus of the research varies as follows: 
(i) Perceptions and attitudes of different customers, employers, managers, and other employees towards sustainability;

(ii) Economic, social, and/or environmental analysis; and

(iii) Measurement and reporting on sustainability practice.

\subsubsection{Perceptions and attitudes of different customers, employers, management, and other employees towards sustainability}

Table 4: Analysis of customers' perceptions and attitudes

\begin{tabular}{|l|c|l|c|}
\hline \multicolumn{1}{|c|}{ Author(s) } & $\begin{array}{c}\text { Year of } \\
\text { publication }\end{array}$ & \multicolumn{1}{|c|}{$\begin{array}{c}\text { Analysis and/or implied } \\
\text { assessment }\end{array}$} & Country \\
\hline Han and Yoon [9] & 2015 & Customers' behaviours & Korea \\
\hline Norazah and Norbayah [10] & 2015 & Customers' behaviours & Malaysia \\
\hline $\begin{array}{l}\text { Peiró-Signe, Segarra-Oña, Verma, } \\
\text { Mondéjar-Jiménez and Vargas- } \\
\text { Vargas [11] }\end{array}$ & 2014 & Customers' perceptions & Spain \\
\hline Berezan, Raab, Yoo and Love [12] & 2013 & $\begin{array}{l}\text { Customers' satisfaction and } \\
\text { behaviours }\end{array}$ & Mexico \\
\hline Pianroj [13] & 2012 & Customers' perceptions & Thailand \\
\hline Marinescu and Ispas [14] & 2012 & Customers' satisfaction & Romania \\
\hline
\end{tabular}

Research studies [9] to [13] mainly consider the perceptions, attitudes, and intentions of customers towards sustainable hotel practices, while Marinescu and Ispas [14] measured customer satisfaction irrespective of sustainable approaches. Norazah and Norbayah [10] found that tourists who repeatedly favour green hotels consider their perceived ability to control their consumption of resources during their stay. Hence, with increasing customers' propensity to use green services, Norazah and Norbayah [10] and Han and Yoon [9] suggest that hotels should perform sustainable operations with optimum resource management, and communicate their sustainable initiatives to tourists. In another analysis, Peiró-Signe et al. [11] found that the highest customer considerations of sustainable practices are achieved in four-star hotels in Spain.

Since hotel clients are the primary source of revenue, their views and concerns are of prior importance. The above research shows that there is an increasing appreciation of customers' interest in sustainable hotel practices. Thus hotels need to include tangible sustainability goals in their operations and services, as expected by their clients. An enhanced sustainability policy would be an added value, resulting in an increase both in customer satisfaction and loyalty and in the hotel's profitability $[9,10,13]$.

Table 5: Analysis of employers' and managers' perceptions and attitudes

\begin{tabular}{|l|c|l|c|}
\hline \multicolumn{1}{|c|}{ Author(s) } & $\begin{array}{c}\text { Year of } \\
\text { publication }\end{array}$ & \multicolumn{1}{|c|}{$\begin{array}{c}\text { Analysis and/or implied } \\
\text { assessment }\end{array}$} & Country \\
\hline Geerts [15] & 2014 & Managers' perceptions & $\begin{array}{c}\text { United } \\
\text { Kingdom }\end{array}$ \\
\hline $\begin{array}{l}\text { Fotiadis, Vassiliadis and Rekleitis } \\
\text { [16] }\end{array}$ & 2013 & Entrepreneurs' perceptions & Greece \\
\hline Wu, Teng and Huang [17] & 2013 & Importance-Performance & Taiwan \\
\hline Cvelbar and Dwyer [18] & 2013 & Importance-Performance & Slovenia \\
\hline $\begin{array}{l}\text { Prayag, Dookhony-Ramphul and } \\
\text { Maryeven [19] }\end{array}$ & 2010 & $\begin{array}{l}\text { Top and middle } \\
\text { management's perceptions }\end{array}$ & Mauritius \\
\hline Rodriguez and Cruz [20] & 2007 & $\begin{array}{l}\text { Relation between managers' } \\
\text { opinions on socio- } \\
\text { environmental responsibility } \\
\text { and performance }\end{array}$ & Spain \\
\hline
\end{tabular}

The hotel entrepreneurs' and managers' perceptions were respectively assessed by Fotiadis et al. [16], Geerts [15], and Prayag et al. [19]. Entrepreneurs compared the socio-environmental benefits with the associated investments and costs. According to Fotiadis et al. [16], the major socioenvironmental benefit is the sustainable development of the tourism region with improved environmental conditions, along with hotels having a good relationship with governmental institutions and the local community. A study by Rodriguez and Cruz [20] further supports the idea that adhering to high social and environmental practices leads to increased profitability. Geerts [15], however, adopts a safer position, arguing that environmental certification did not systematically improve profitability, although he agrees that such certification did help to prevent 
greenwashing, and that the implementation of sustainability practices, in view of the certification, did allow some cost savings. According to Geerts, a lack of improved profitability was mainly due to poor external communication and because the certification was not necessarily a criterion that hotel clients considered while making their hotel booking. Geerts [15] further states that, with increasingly environmentally conscious guests, improved regulation of the certification schemes, and better communication, "certification schemes can become part of the hotel's brand image". Prayag et al. [19], on their side, suggest the adoption of "proper tourism policy, hotel development and management of tourism impacts". In other studies, Wu et al. [17] and Cvelbar and Dwyer [18] analysed the perception of hoteliers about the importance and performance of the green practices of hotels in Taiwan and Slovenia respectively. The results suggest that hoteliers value environmentally sustainable approaches mainly as a way to achieve better profitability.

Table 6: Analysis of employees' perceptions and attitudes

\begin{tabular}{|l|c|l|c|}
\hline \multicolumn{1}{|c|}{ Author(s) } & $\begin{array}{c}\text { Year of } \\
\text { publication }\end{array}$ & \multicolumn{1}{|c|}{$\begin{array}{c}\text { Analysis and/or implied } \\
\text { assessment }\end{array}$} & Country \\
\hline $\begin{array}{l}\text { Juwaheer, Nunkoo, Pudaruth and } \\
\text { Seeboo [21] }\end{array}$ & 2014 & Employees' perceptions & Mauritius \\
\hline Park and Levy [22] & 2014 & $\begin{array}{l}\text { Perceptions of frontline } \\
\text { employees }\end{array}$ & $\begin{array}{c}\text { United } \\
\text { States of } \\
\text { America } \\
\text { (USA) }\end{array}$ \\
\hline Murray and Ayoun [23] & USA \\
\hline
\end{tabular}

Employees' perceptions were studied by Juwaheer et al. [21]. The latter identified factors contributing to sustainable tourism, and explored employees' perceptions of resource management practices in Mauritian hotels. The results suggest that the respondents are generally favourable to sustainable practices. However, the authors proposed further in-depth engineering research on energy, water, and waste management, since they only performed a quantitative management study.

Park and Levy [22] also assessed the perceptions of frontline hotel employees of corporate social responsibility (CSR) activities. According to them, CSR activities are not limited to green practices, but include host community, colleagues', and customers' activities. The findings suggest that CSR activities enhance frontline employees' engagement with their organisations. At the same time, these activities improve the attractiveness of career opportunities for competent potential employees, and motivate existing frontline staff to give meaning to their career as they achieve the hotels' goals.

Murray and Ayoun [23] also support the idea that the adoption of sustainable practices in the hotel sector is appealing to job seekers. A group of university students who were interviewed highly favoured the diversity and human rights dimensions of sustainable development, but argued that philanthropy is outmoded. These students affirmed that local people and minorities deserve equal and fair access to hotel employment, and that equity, equal opportunity and respect for human rights are imperative in the workplace.

In the light of the above, it becomes clear that there needs to be a win-win solution in respect of sustainability and associated investments and costs to improve hotel competitiveness, as sustainable practices have the potential to impact both marketing and human resource strategies.

\subsubsection{Economic, social, and/or environmental analysis}

Recent research ([24] to [39]) emphasises the importance of hotels adopting green technologies according to a cost-benefit ratio. Several approaches, addressing different budgetary and technical constraints, are applied [24]. Khodabocus and Beekoo [38] and Deehul and Khodabocus [39] research the implementation of an environmental strategy using ISO 14001 in selected hotels in Mauritius, while Yusof and Jamaludin [36] focused on the participation rate in environmental approaches in the Malaysian hospitality industry. In the latter study, in-depth interviews and observations were used, and the findings showed that the operators adopted greener approaches for "energy, waste and water", while participation was based less on "indoor air quality, sustainable management of the site, renewable energy and rainwater harvesting system" [36]. 
Table 7: Environmental analysis

\begin{tabular}{|l|c|l|c|}
\hline \multicolumn{1}{|c|}{ Author(s) } & $\begin{array}{c}\text { Year of } \\
\text { publication }\end{array}$ & \multicolumn{1}{|c|}{$\begin{array}{c}\text { Analysis and/or implied } \\
\text { assessment }\end{array}$} & Country \\
\hline Chan, Okumus and Chan [24] & 2017 & Environmental & Hong Kong \\
\hline $\begin{array}{l}\text { Coles, Warren, Borden and Dinan } \\
\text { [25] }\end{array}$ & 2017 & Environmental & UK \\
\hline $\begin{array}{l}\text { Manganari, Dimara and Theotokis } \\
\text { [26] }\end{array}$ & 2016 & $\begin{array}{l}\text { Environmental } \\
\text { [Review paper between 2003 } \\
\text { and 2014] }\end{array}$ & International \\
\hline $\begin{array}{l}\text { Noordzy, Ricaurte, James and Wu } \\
\text { [27] }\end{array}$ & 2016 & Environmental & China \\
\hline $\begin{array}{l}\text { Xu, Chan, Visscher, Zhang and Wu } \\
\text { [28] }\end{array}$ & 2015 & Building energy efficiency & China \\
\hline $\begin{array}{l}\text { Bruns-Smith, Choy, Chong and } \\
\text { Verma [29] }\end{array}$ & 2015 & Environmental & USA \\
\hline Kasim [30] & 2015 & Environmental & Malaysia \\
\hline $\begin{array}{l}\text { Leonidou, Leonidou, Fotiadis and } \\
\text { Aykol [31] }\end{array}$ & 2015 & Environmental & International \\
\hline $\begin{array}{l}\text { Kasim, Gursoy, Okumus and Wong } \\
\text { [32] }\end{array}$ & 2014 & Water management \\
\hline $\begin{array}{l}\text { Walsman, Verma and } \\
\text { Muthulingam [33] }\end{array}$ & 2014 & Environmental & Malaysia \\
\hline $\begin{array}{l}\text { Zhang, Joglekar, Verma and } \\
\text { Heineke [34] }\end{array}$ & 2014 & Environmental & $\begin{array}{c}\text { United } \\
\text { Fraj, Matute and Melero [35] }\end{array}$ \\
\hline Yusof and Jamaludin [36] & 2014 & Environmental & America \\
\hline Rogerson and Sims [37] & 2013 & Environmental & USA \\
\hline Khodabocus and Beekoo [38] & Environmental & Spain \\
\hline Deehul and Khodabocus [39] & Environmental & Mauritaysia \\
\hline $\begin{array}{l}\text { Poinen, Bokhoree, Balnac and } \\
\text { Mohee [40] }\end{array}$ & Environmental & Mauritius \\
\hline
\end{tabular}

There is, however, a mixed outcome on the relationship between environmental measures and improved green competitive advantage and financial gains. In some studies focusing on American hotels, the impact of the Leadership in Energy and Environmental Design (LEED) certification standard for green buildings enabled increased profitability, while other studies were inconclusive [33].

Table 8: Social analysis

\begin{tabular}{|l|c|l|c|}
\hline \multicolumn{1}{|c|}{ Author(s) } & $\begin{array}{c}\text { Year of } \\
\text { publication }\end{array}$ & \multicolumn{1}{|c|}{$\begin{array}{c}\text { Analysis and/or implied } \\
\text { assessment }\end{array}$} & Country \\
\hline Park and Levy [22] & 2014 & $\begin{array}{l}\text { Perceptions of frontline } \\
\text { employees }\end{array}$ & USA \\
\hline Murray and Ayoun [23] & 2011 & $\begin{array}{l}\text { Future employees' } \\
\text { perceptions }\end{array}$ & USA \\
\hline
\end{tabular}

A discussion of these papers occurs above under the heading 'Analysis of employees' perceptions and attitudes'.

Table 9: Economic, social, and environmental analysis

\begin{tabular}{|l|c|l|c|}
\hline \multicolumn{1}{|c|}{ Author(s) } & $\begin{array}{c}\text { Year of } \\
\text { publication }\end{array}$ & \multicolumn{1}{|c|}{$\begin{array}{c}\text { Analysis and/or implied } \\
\text { assessment }\end{array}$} & Country \\
\hline $\begin{array}{l}\text { Melissen, Cavagnaro, Damen and } \\
\text { Düweke [41] }\end{array}$ & 2016 & $\begin{array}{l}\text { Economic, social, and } \\
\text { environmental }\end{array}$ & $\begin{array}{c}\text { Holland/ } \\
\text { Netherlands }\end{array}$ \\
\hline Stylos and Vassiliadis [42] & 2015 & $\begin{array}{l}\text { Economic, social, and } \\
\text { environmental }\end{array}$ & Greece \\
\hline
\end{tabular}

Studies by Melissen, Cavagnaro, Damen, and Düweke [41] and by Stylos and Vassiliadis [42] looked at the three pillars of sustainability (economic, social, and environmental). The objective of Melissen et al. [41] was to assess whether the hotel industry was prepared to face the challenge of sustainable development. This study was carried out through in-depth interviews among 12 leading Dutch hotels. The authors concluded that the hotel industry was still not achieving its full sustainability potential, and needed assistance to satisfy the sustainable requirements of customers and to institutionalise 
sustainability. Stylos and Vassiliadis [42] suggested that hotel star ratings play an important role in determining "the perceived importance of financial measures as well as the application of social and environmental measures". The focus of the study of Stylos and Vassiliadis [42] was on four- and five-star hotels in Greece. The authors argued that the four-star hotels would be more competitive if they addressed the three pillars of sustainability, while five-star hotels might become pioneers in sustainable development if the environmental, social, and economic sustainability concepts were fully implemented [42].

As can be seen, some hotels focus on either the environmental or the social pillar of sustainability, while other hotels tend to address all three. Since the focus on sustainability is relatively new in hospitality [42], it can be argued that there is room for progress in the study of sustainability in this sector.

\subsubsection{Measurement of and reporting on sustainability practice}

Table 10: Sustainability performance indicators and measurements

\begin{tabular}{|l|c|l|c|}
\hline \multicolumn{1}{|c|}{ Author(s) } & $\begin{array}{c}\text { Year of } \\
\text { publication }\end{array}$ & \multicolumn{1}{|c|}{$\begin{array}{c}\text { Analysis and/or implied } \\
\text { assessment }\end{array}$} & Country \\
\hline $\begin{array}{l}\text { Dos Santos, Méxas and Meiriño } \\
\text { [43] }\end{array}$ & 2017 & Criteria & Slovenia \\
\hline Mihalič, Žabkar and Cvelbar [44] & 2012 & $\begin{array}{l}\text { Hotel sustainability business } \\
\text { model (HSBM) }\end{array}$ & Taiwan \\
\hline Hu et al. [45] & 2015 & Carbon footprint & USA \\
\hline Chong and Ricaurte [46] & 2014 & Benchmarking & $\begin{array}{c}\text { International } \\
\text { / Global }\end{array}$ \\
\hline Yu-guo and Zhen-fang [47] & 2014 & Carbon accounting & USA \\
\hline Withiam [48] & 2013 & Benchmarking & \begin{tabular}{c} 
International \\
\hline Filimonau [49]
\end{tabular} \\
\hline Lai, Yik and Man [50] & 2012 & $\begin{array}{l}\text { Carbon calculators [review } \\
\text { paper] }\end{array}$ & Hong-Kong \\
\hline
\end{tabular}

Studying sustainability is difficult without performance indicators and measurements. Following a bibliometric analysis, Dos Santos et al. [43] first presented "sustainable criteria verified in current hotel management models", then structured the latter into more holistic environmental, sociocultural, political, and economic criteria. Mihalič et al. [44] used expert opinion and the Delphi method to refine 79 sustainability indicators down to 36 HSBM operational ones that were used to study Slovenian hotels' sustainability. In addition, after a landmark analysis of more than 1,000 hotels, Chong and Ricaurte [46] presented the first Cornell Hotel Sustainability Benchmarking (CHSB) study with six energy and carbon key performance indicators (KPI). This study involved mostly the American hotels of nine global companies; the only non-USA hotels was in Hong Kong-ShenzhenMacau in China.

Research was also carried out specifically on hotel carbon footprints. Filimonau [49] performed a critical review of 50 online carbon calculators for holiday travel, including hotels. "Poor accessibility of the background data, inconsistencies in the multiplying factors used and inhomogeneity in the appraisal methods" were noted, and improvements to the calculators' quality and reliability were suggested. Lai, Yik and Man [50] and Hu et al. [45] calculated hotel footprints in Hong Kong and Taiwan respectively, the latter emphasising the hotel life cycle. Yu-guo and Zhen-fang [47] reviewed the accounting of carbon dioxide emissions for tourism on world-wide, regional, national, and unit scales, and they proposed improvements to the hotel unit.

Table 11: Facilities management

\begin{tabular}{|l|c|l|c|}
\hline \multicolumn{1}{|c|}{ Author(s) } & $\begin{array}{c}\text { Year of } \\
\text { publication }\end{array}$ & \multicolumn{1}{|c|}{$\begin{array}{c}\text { Analysis and/or implied } \\
\text { assessment }\end{array}$} & Country \\
\hline $\begin{array}{l}\text { Nielsen, Sarasoja and Galamba } \\
\text { [51] }\end{array}$ & 2016 & $\begin{array}{l}\text { Facilities management } \\
\text { [Review paper] }\end{array}$ & $\begin{array}{c}\text { International } \\
\text { /global }\end{array}$ \\
\hline
\end{tabular}

On their side, Nielsen et al. [51] systematically reviewed the available literature on sustainable facilities management, and assessed nine current research areas, including "sustainability tools and standards, building performance, and sustainability management in the built environment". 
Table 12: Economic and environmental sustainability performance indicators

\begin{tabular}{|l|c|l|c|}
\hline \multicolumn{1}{|c|}{ Author(s) } & \multicolumn{1}{|c|}{$\begin{array}{c}\text { Year of } \\
\text { publication }\end{array}$} & \multicolumn{1}{|c|}{$\begin{array}{c}\text { Analysis and/or implied } \\
\text { assessment }\end{array}$} & Country \\
\hline $\begin{array}{l}\text { Cadarso, Gómez, López and } \\
\text { Tobarra [52] }\end{array}$ & 2016 & $\begin{array}{l}\text { Carbon footprint and } \\
\text { investment }\end{array}$ & Spain \\
\hline Singal [53] & 2014 & Performance & International \\
\hline $\begin{array}{l}\text { García-Pozo, Sánchez-Ollero and } \\
\text { Marchante-Mera [54] }\end{array}$ & 2013 & Performance & Spain \\
\hline
\end{tabular}

Singal [53] and García-Pozo et al. [54] concluded that hotels should invest in environmentally sustainable measures to improve profitability. From an analysis of data (1991 to 2011) obtained from the Morgan Stanley Capital International (MSCl) environmental, social, and governance (ESG) indices, and from Standard and Poor's financial services (SandP) credit ratings on 16,325 firm-years, of which 624 firm-years related to the hospitality and tourism sector, Singal [53] shows that environmental sustainability improves hotels' financial performance. A similar conclusion was reached by GarcíaPozo et al. [54] in their study in Andalusia (Southern Spain), which drew attention to the fact that hotels charge higher prices if environmental measures are implemented. Hoteliers' sustainability responsibilities are also increased by the inclusion of carbon footprint calculations in tourism investment [52].

Table 13: Reporting of sustainability practice

\begin{tabular}{|l|c|l|c|}
\hline \multicolumn{1}{|c|}{ Author(s) } & $\begin{array}{c}\text { Year of } \\
\text { publication }\end{array}$ & \multicolumn{1}{|c|}{$\begin{array}{c}\text { Analysis and/or implied } \\
\text { assessment }\end{array}$} & Country \\
\hline Jones, Hillier and Comfort [55] & 2014 & Reporting & $\begin{array}{c}\text { International } \\
\text { /global }\end{array}$ \\
\hline Lai [56] & 2014 & Reporting & Hong Kong \\
\hline
\end{tabular}

As a final point, the reporting and communication of sustainability commitments, approaches, and achievements are concerns for both governments and hoteliers. In Canada, Japan, Australia, the UK, and the USA, reporting of greenhouse gases (GHG) is mandatory under certain conditions [56]; while in other countries, such reporting is voluntary. Jones et al. [55] reviewed hoteliers' communication on their sustainable approaches, and were critical that the hotels' actual commitments were geared more towards business gains than to real concerns for the preservation and improvement of our shared environment. The authors suggested the implementation of a more transparent and reliable reporting process, with independent external assurance, to create a shift from a "weak" to a "strong" sustainability approach in the hotel sector, with "weak" referring to "sustainability initiative and programmes developed within existing economic and social systems", and "strong" referring to "much more radical changes in both economy and society" $[55,57]$.

This section shows increasing concerns about sustainable practices in hotels around the world. The development of a holistic strategy execution system, the use of performance indicators, measurements and benchmarks, and a transparent reporting of commitments and achievements will encourage long-term hotel sustainability.

\subsection{Existing worldwide research on strategy execution and general strategy approaches in hotels}

Here the research focus is as follows:

- $\quad$ Strategy execution in hotels; and

- $\quad$ General hotel strategy approaches.

Table 14: Strategy execution analysis

\begin{tabular}{|l|c|l|c|}
\hline \multicolumn{1}{|c|}{ Author(s) } & $\begin{array}{c}\text { Year of } \\
\text { publication }\end{array}$ & \multicolumn{1}{|c|}{ Analysis and/or implied assessment } & Country \\
\hline Leslie [58] & 2008 & Strategy implementation / execution & $\begin{array}{c}\text { South } \\
\text { Africa }\end{array}$ \\
\hline $\begin{array}{l}\text { Mutindi, Namusonge and } \\
\text { Obwogi [59] }\end{array}$ & 2013 & Strategic management & Kenya \\
\hline Wang, Chen and Chen [60] & 2012 & $\begin{array}{l}\text { Total quality management (TQM), } \\
\text { marketing, and performance }\end{array}$ & Taiwan \\
\hline Phillips and Louvieris [61] & 2008 & Performance measurement & UK \\
\hline
\end{tabular}


For his doctoral thesis, Leslie [58] developed a model for practitioners in the South African hotel industry, depicted in Figure 3.

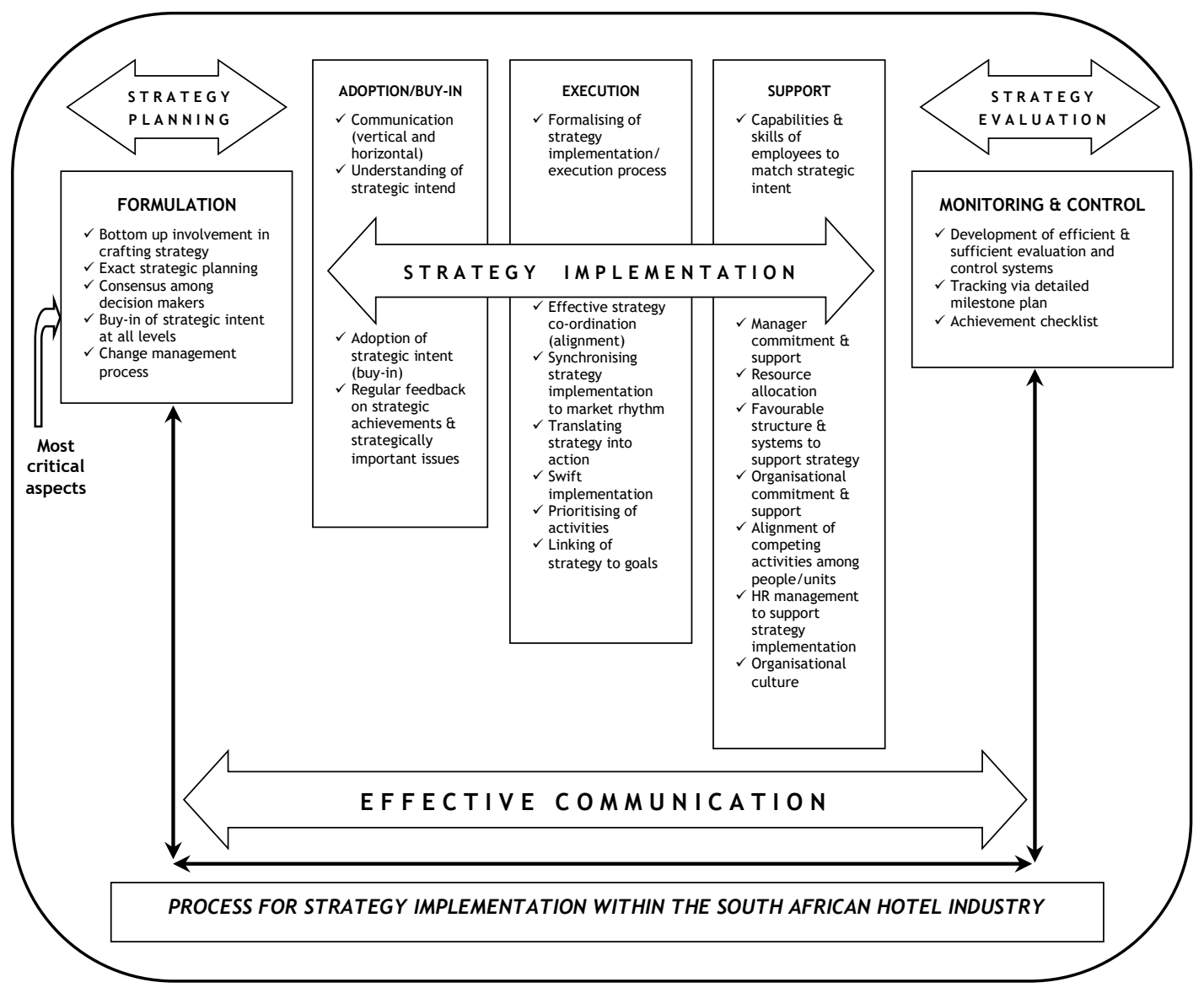

Figure 3: Final revised model for assisting practitioners in the South African hotel industry to move from strategic planning to strategic implementation [57]

The above model shows various actions grouped under the strategy planning, the strategy implementation and the strategy evaluation headers. Effective communication is also recommended throughout the process. For future research, Leslie [58] recommended the development of "a toolkit or model that is idiosyncratic to the hotel industry". This tool should enable the monitoring of strategy execution.

Other research includes the study of Mutindi et al. [59] of the influence of conceptualised strategic management drivers (customer relationship management strategy, strategic planning, competitive positioning, information communication technology, and organisational learning) on the Kenyan coast hotel industry's performance. Moreover, the results of Wang et al. [60] showed that TQM and market orientation positively influence hotel performance, while external environmental factors act as a moderator between TQM, market orientation, and hotel performance. This study highlighted the importance of a holistic approach. In addition, the results of Phillips and Louvieris [61] revealed four key concepts that influence performance measurement and evaluation in their hotel sample study: "budgetary control with a view to increasing total revenue, the undertaking of customer relationship management as a means of improving quality of service and customer retention, the necessity for strategic management in managing internal business processes, and collaboration (both inter and intra) to drive innovation and learning". Phillips and Louvieris [61] also proposed a balanced scoreboard template for hotels. 
Table 15: Hotel strategy approaches analysis

\begin{tabular}{|l|c|l|c|}
\hline \multicolumn{1}{|c|}{ Author(s) } & $\begin{array}{c}\text { Year of } \\
\text { publication }\end{array}$ & \multicolumn{1}{|c|}{$\begin{array}{c}\text { Analysis and/or implied } \\
\text { assessment }\end{array}$} & Country \\
\hline Dash and Mahapatra [62] & 2016 & Competitive advantages & India \\
\hline Mutheu [63] & 2013 & Competitive advantages & Kenya \\
\hline Yilmaz [64] & 2013 & Efficiency & Turkey \\
\hline Daghfous and Barkhi [65] & 2009 & Information technology (IT) & UAE \\
\hline
\end{tabular}

Both Dash and Mahapatra [62] of India, and Mutheu [63] of Kenya, acknowledged human resources (HR) practices as a significant driver of hotel competitive advantage. Mutheu [63] highlighted the importance of IT, mainly as part of an e-commerce marketing strategy, and recommended a greater focus on relationship marketing. The exploratory study of Daghfous and Barkhi [65] shed light on the wise use of IT as a way to enhance hotel performance through service excellence and profitability.

To complete this part, it is essential to mention the analysis of Yilmaz [64] of the link between business strategies and data envelopment analysis (DTA) efficiency level in hotels.

The above illustrates the importance of adopting appropriate strategies and ensuring effective and efficient strategy execution to achieve hotel performance. The need for a strategy execution monitoring tool or model was also highlighted by Leslie [58].

3.3 Existing worldwide systems thinking (ST) and system dynamics (SD) tools in hotel and tourism

Applications of ST and SD can be in hotels or tourism, or both.

Table 16: Hotel applications analysis

\begin{tabular}{|l|c|l|c|}
\hline \multicolumn{1}{|c|}{ Author(s) } & $\begin{array}{c}\text { Year of } \\
\text { publication }\end{array}$ & $\begin{array}{c}\text { Application, analysis, and/or } \\
\text { implied assessment }\end{array}$ & Country \\
\hline Scholz and Voracek [66] & 2016 & Hotel & Europe \\
\hline Lacagnina and Provenzano [67] & 2009 & Hotel & $\begin{array}{c}\text { General } \\
\text { application }\end{array}$ \\
\hline Georgantzas [68] & 2003 & Hotel & Cyprus \\
\hline
\end{tabular}

Three studies were found to be relevant to the application of SD in the hotel sector. After an initial model by Georgantzas [68] on Cyprus' hotel value chain and profitability, Lacagnina and Provenzano [67] developed an integrated SD-DTA model to analyse the outcome of implemented policies. Finally, a study by Scholz and Voracek [66] from the Department of Travel and Tourism and the Department of Technical Studies respectively - both departments in the College of Polytechnics Jihlava, Jihlava, Czech Republic - developed an interactive SD model for hotels and tested several scenarios. The scenario analysis for a case study hotel proved useful in choosing appropriate strategy options.

Table 17: Tourism applications analysis

\begin{tabular}{|l|c|l|c|}
\hline \multicolumn{1}{|c|}{ Author(s) } & $\begin{array}{c}\text { Year of } \\
\text { publication }\end{array}$ & $\begin{array}{c}\text { Application, analysis, and/or } \\
\text { implied assessment }\end{array}$ & Country \\
\hline $\begin{array}{l}\text { Pizzitutti, Walsh, Rindfuss, } \\
\text { Gunter, Quiroga, Tippett and } \\
\text { Mena [69] }\end{array}$ & 2016 & Tourism & Ecuador \\
\hline Anctil and Le Blanc [70] & 2016 & Tourism and hotel & $\begin{array}{c}\text { General } \\
\text { application }\end{array}$ \\
\hline $\begin{array}{l}\text { Law, De Lacy, McGrath, } \\
\text { Whitelaw, Lipman and Buckley } \\
\text { [71] }\end{array}$ & 2012 & Tourism & Egypt \\
\hline Thanh and Smith [72] & 2015 & Tourism & Vietnam \\
\hline Nguyen and Bosch [73] & 2012 & Tourism & Vietnam \\
\hline Thanh, Bosch and Maani [74] & 2011 & Tourism & Vietnam \\
\hline $\begin{array}{l}\text { Nguyen, Graham, Ross, Maani and } \\
\text { Bosch [75] }\end{array}$ & 2011 & Tourism & Vietnam \\
\hline Thanh and Bosch [76] & 2010 & Tourism & Vietnam \\
\hline Thanh and Maani [77] & 2010 & Tourism & Vietnam \\
\hline
\end{tabular}


Four main studies were found to be relevant to the application of SD in tourism scenario analyses. Pizzitutti et al. [69] and Law et al. [71] developed decision-support systems using SD to enable scenario analyses to assist policy-makers for the proper tourism management of the Galapagos Islands (Ecuador) and Sharm El Sheikh (Egypt) respectively. Both models considered sustainability factors in their respective contexts.

Thanh and Smith [72], Nguyen and Bosch [73], Thanh, Bosch and Maani [74], Nguyen et al. [75], Thanh and Bosch [76] and Thanh and Maani [77] used ST and SD to perform scenario analysis to assist in preserving the ecosystem of the United Nations Educational, Scientific and Cultural Organization (UNESCO) designated Cat Ba Biosphere Reserve in Vietnam. The golden-headed langur, one of the world's top 25 most endangered species, can only be found in this reserve; and the growing number of tourists eventually became a threat to the Cat Ba Island's ecosystem. These studies were essential in strategy development and execution of a sustainable tourism policy for this world nature reserve.

Anctil and Le Blanc [70] developed an educational simulation tool for integrated coastal tourism development in developing countries. The use of the developed model for simulating different scenarios over a 20-year time span unveiled appropriate approaches in solid waste and wastewater treatment for hotels, accommodation in neighbouring communities, and other tourism infrastructure. The aim was to maintain an acceptable fish stock level in the seas surrounding coastal tourism destinations, while at the same time considering an optimum number of tourists. Enabling scenario analysis through this education model-tool favours long-term sustainable development policy decisions in developing countries.

The above review illustrates the publications and the use of ST and SD in hotel and tourism strategy decision analysis, decision-making, and execution. Such approaches are considered to be part of the future leadership and management style for the hotel sector [66].

\section{CONCLUSION AND RECOMMENDATIONS}

A systematic literature review has been carried out with the aim of evaluating the potential use of ST and SD to develop a sustainable hotel strategy execution (SHSE) model. This study has led to the review of the existing contemporary research on hotel sustainability analyses and practices in several countries. Recent publications on state-of-the-art ST and SD scenario analysis tools in tourism and hotels have also been reviewed and analysed.

Although there have been advances in the use of ST and SD, there is still a need to develop a fullyfledged SHSE model using ST and SD. Such a simulation model would help hotels to improve their competitiveness by having an effective SHSE. Our planet, being vulnerable to climate change, also needs a sustainable use of our limited available resources in order to preserve and enhance its ecological balance. SD modelling will allow hotels' consumption of such resources to be forecast by enabling the analysis of the internal technological and organisational processes, and of hotels' interactions with their environment. Besides, one of the most important assets of a country is its people, and this includes the hotels' labour force. Ensuring that the staff are highly competent and motivated would bring about excellent service delivery.

The use of SD provides new possibilities in hotel strategy decision-making and execution, since it allows an interactive scenario analysis on a medium- and long-term basis. In fact, SD modelling should fuel the implementation of the best strategies to deliver sustainable quality services. Monitoring and control would also be less challenging as the chosen strategy is executed. Furthermore, during strategy execution, it would be easier to analyse the three pillars of sustainability (economic, social, and environmental). This would be an opportunity for hotel and tourism stakeholders, whose undeniable aim is to be profitable, to address social and environmental needs and concerns.

In addition, any tourism destination (region or country) has limited resources. This opens up research possibilities on the growth capacity of its hotel sector. Further research could thus focus on effective strategy execution for a tourism destination's sustainable hotel sector, and determine the optimum number of hotel rooms and tourists that the destination could accommodate for an increase in revenue, while at the same time maintaining its socio-ecological equilibrium. 
The development of the SHSE model/tool will be done initially for a typical hotel with an emphasis on environmental sustainability. Further SD strategy and management decision-support tools could be developed later for the overall hotel sector and/or tourism industry of any tourism region or country.

\section{REFERENCES}

[1] World Tourism Organisation (UNWTO). 2017. UNWTO Annual Report 2016. Madrid: UNWTO.

[2] World Tourism Organisation (UNWTO). 2017. UNWTO Tourism Highlights 2017 Edition. Madrid: UNWTO.

[3] Hotel Energy Solutions. 2011. Hotel Energy Solutions: Fostering innovation to fight climate change Public report. Hotel Energy Solutions project publications.

[4] World Tourism Organisation (WTO) and United Nations Environment Programme (UNEP). 2005. Making tourism more sustainable: $A$ guide for policy makers. Madrid: WTO \& Paris: UNEP.

[5] Sterman, J.D. 2000. Business dynamics: Systems thinking and modelling for a complex world. Boston: Irwin/McGraw-Hill.

[6] Forrester J.W. 2007. System dynamics: A personal view of the first fifty years. System Dynamics Review, 23(2-3), pp. 359-370.

[7] Stimie, J.E. \& Vlok, P.J. 2016. Sustainable strategy execution for engineering managers. Stellenbosch: Stellenbosch University.

[8] International Standard Organization (ISO). 2010. Guidance on social responsibility. Geneva: International Standard Organisation.

[9] Han, H. \& Yoon, H.J. 2015. Hotel customers' environmentally responsible behavioral intention: Impact of key constructs on decision in green consumerism. International Journal of Hospitality Management, 45, pp. 22-33.

[10] Norazah, M.S. \& Norbayah, M.S. 2015. Consumers' environmental behaviour towards staying at a green hotel: Moderation of green hotel knowledge. Management of Environmental Quality: An International Journal, 26(1), pp. 103-117, doi: 10.1108/MEQ-02-2014-0023.

[11] Peiró-Signe, A., Segarra-Oña, M., Verma, R., Mondéjar-Jiménez, J. \& Vargas-Vargas, M. 2014. The impact of environmental certification on hotel guest ratings. Cornell Hospitality Quarterly, 55(1), pp. 4051.

[12] Berezan, O., Raab, C., Yoo, M. \& Love, C. 2013. Sustainable hotel practices and nationality: The impact on guest satisfaction and guest intention to return. International Journal of Hospitality Management, 34, pp. 227-233.

[13] Pianroj, N. 2012. Perceived customer loyalty toward green hotels: South of Thailand. AU Journal of Management, 10(2), pp. 40-50.

[14] Marinescu, R.C. \& Ispas, R. 2012. Achieving sustainable tourism through customer satisfaction. Annals of the University of Oradea: Economic Science, 1(2) pp. 349-354.

[15] Geerts, W. 2014. Environmental certification schemes: Hotel managers' views and perceptions. International Journal of Hospitality Management, 39, pp. 87-96.

[16] Fotiadis, A.K., Vassiliadis, C.A. \& Rekleitis, P.D. 2013. Constraints and benefits of sustainable development: A case study based on the perceptions of small-hotel entrepreneurs in Greece. Anatolia: An International Journal of Tourism and Hospitality Research, 24(2) pp. 144-161.

[17] Wu, K-S., Teng, Y-M. \& Huang, D-M. 2013. Are lodging really go green? Empirical investigation of the sustainability practice from the hoteliers by importance-performance analysis (IPA). Analysis: Life Science Journal, 10(4), pp. 418-427.

[18] Cvelbar, L.K. \& Dwyer, L. 2013. An importance-performance analysis of sustainability factors for longterm strategy planning in Slovenian hotels. Journal of Sustainable Tourism, 21(3), pp. 487-504.

[19] Prayag, G., Dookhony-Ramphul, K. \& Maryeven, M. 2010. Hotel development and tourism impacts in Mauritius: Hoteliers' perspectives on sustainable tourism. Development Southern Africa, 27(5), pp. 697 712.

[20] Rodriguez, F.J.G. \& Del Mar Armas Cruz, Y. 2007. Relation between socio-environmental responsibility and performance in hotel firms. International Journal of Hospitality Management, 2007, 26(4), pp. 824839.

[21] Juwaheer, T.D., Nunkoo, R., Padaruth, S. \& Seeboo, H. 2014. Analyzing sustainable tourism practices for the hotel industry of Mauritius. $4^{\text {th }}$ Advances in Hospitality and Tourism Marketing and Management Conference, 25-27 July 2014, Mauritius.

[22] Park, S-Y. \& Levy, S.E. 2014. Corporate social responsibility: Perspectives of hotel frontline employee. Journal of Contemporary Hospitality Management, 26(3), pp. 332-348.

[23] Murray, D.W. \& Ayoun, B.M. 2011. Hospitality student perceptions on the use of sustainable business practices as a means of signaling attractiveness and attracting future employees. Journal of Human Resources in Hospitality and Tourism, 10, pp. 60-79.

[24] Chan, E.S.W., Okumus, F. \& Chan, W. 2017. The applications of environmental technologies in hotels. Journal of Hospitality Marketing and Management, 26(1), pp. 23-47.

[25] Coles, T., Warren, N., Borden, D.S. \& Dinan, C. 2017. Business models among SMTEs: Identifying attitudes to environmental costs and their implications for sustainable tourism. Journal of Sustainable Tourism, 25(4), pp. 471-488.

[26] Manganari, E.E., Dimara, E. \& Theotokis, A. 2016. Greening the lodging industry: Current status, trends and perspectives for green value. Current Issues in Tourism, 19(3), pp. 223-242. 
[27] Noordzy, G., Ricaurte, E., James, G. \& Wu, M. 2016. Environmental implications of hotel growth in China: Integrating sustainability with hotel development. Cornell Hospitality Report, 16(12), pp. 3-9.

[28] Xu, P., Chan, E.H.W., Visscher, H.J., Zhang X. \& Wu Z. 2015. Sustainable building energy efficiency retro fit for hotel buildings using EPC mechanism in China: Analytic network process (ANP) approach. Journal of Cleaner Production, 107, pp. 378-388.

[29] Bruns-Smith, A., Choy, V., Chong, H. \& Verma, R. 2015. Environmental sustainability in the hospitality industry: Best practices, guest participation, and customer satisfaction. Cornell Hospitality Report, 15(3), pp. 6-16.

[30] Kasim, A. 2015. Environmental management system (EMS): Postulating the value of its adoption of organizational learning in hotels. International Journal of Contemporary Hospitality Management, 27(6), pp. 1233-1253.

[31] Leonidou, L.C., Leonidou, C.N., Fotiadis, T.A. \& Aykol, B. 2015. Dynamic capabilities driving an ecobased advantage and performance in global hotel chains: The moderating effect of international strategy. Tourism Management, 50, pp. 268-280.

[32] Kasim, A., Gursoy, D., Okumus, F. \& Wong, A. 2014. The importance of water management in hotels: A framework for sustainability through innovation. Journal of Sustainable Tourism, 22(7), pp. 1090-1107.

[33] Walsman, M., Verma, R. \& Muthulingam, S. 2014. The impact of LEED certification on hotel performance. Cornell Hospitality Report, 14(15), pp. 6-13.

[34] Zhang, J.J., Joglekar, N., Verma, R. \& Heineke, J. 2014. Exploring the relationship between ecocertifications and resource efficiency in U.S. hotels. Cornell Hospitality Report, 14(7), pp. 6-16.

[35] Fraj, E., Matute, J. \& Melero, I. 2014. Environmental strategies and organizational competitiveness in the hotel industry: The role of learning and innovation as determinants of environmental success. Tourism Management, 46, pp. 30-42.

[36] Yusof, Z.B. \& Jamaludin, M. 2013. Green approaches of Malaysian green hotels and resorts. Procedia Social and Behavioral Sciences, 85, pp. 421-431.

[37] Rogerson, J.M. \& Sims, S.R. 2012. The greening of urban hotels in South Africa: Evidence from Gauteng. Urban Forum, 23, pp. 391-407.

[38] Khodabocus, F. \& Beekoo, C. 2010. Devising a strategy to implement an environmental management system based on ISO 14001:2004 in the hotel sector. University of Mauritius Research Journal, 16(1), pp. 138-167.

[39] Deehul, M. \& Khodabocus, B.F. 2010. Adoption and maintenance of environmental management system in the tourism sector. Journal of Environmental Research and Development, 5(2), pp. 443-453.

[40] Poinen, P., Bokhoree, C., Balnac, K. \& Mohee, R. 2009. Evaluating and forecasting future energy consumption patterns for a sustainable hotel sector in Mauritius. International Journal of Environment, Cultural, Economic and Social Sustainability, 5(2), pp. 129-140.

[41] Melissen, F., Cavagnaro, E., Damen, M. \& Diweke, A. 2016. Is the hotel industry prepared to face the challenge of sustainable development? Journal of Vacation Marketing, 22(3), pp. 227-238.

[42] Stylos, N. \& Vassiliadis, C. 2015. Differences in sustainable management between four- and five-star hotels regarding the perceptions of three-pillar sustainability. Journal of Hospitality Marketing and Management, 24(8), pp. 791-825.

[43] Dos Santos, R.A., Méxas, M.P. \& Meiriño, M.J. 2017. Sustainability and hotel business: Criteria for holistic, integrated and participative development. Journal of Cleaner Production, 142, pp. 217-224.

[44] Mihalič, T., Žabkar, V. \& Cvelbar, L.K. 2012. A hotel sustainability business model: Evidence from Slovenia. Journal of Sustainable Tourism, 20(5), pp. 701-719.

[45] Hu, A.H., Huang, C-Y., Chen, C-F., Kuo, C-H. \& Hsu, C-W. 2015. Assessing carbon footprint in the life cycle of accommodation services: The case of an international tourist hotel. International Journal of Sustainable Development and World Ecology, 22(4), pp. 313-323.

[46] Chong, H. \& Ricaurte, E. 2014. Hotel sustainability benchmarking. Cornell Hospitality Report, 14(11), pp. 6-27.

[47] Yu-guo, T. \& Zhen-Fang, H. 2014. Review of accounting for carbon dioxide emissions from tourism at different spatial scales. Acta Ecologica Sinica, 34, pp. 246-254.

[48] Withiam, G. 2013. Toward sustainable hotel and restaurant operations. Cornell Hospitality Roundtable Proceedings, 5(4), pp. 6-11.

[49] Filimonau, V. Carbon calculators as a tool for carbon impact appraisal of holiday travel: A critical review. Worldwide Hospitality and Tourism, 4(4), pp. 302-331.

[50] Lai, J.H.K., Yik, F.W.H. \& Man, C.S. 2012. Carbon audit: A literature review and an empirical study on a hotel. Facilities, 30(9/10), pp. 417-431.

[51] Nielsen, S.B., Sarasoja, A-L. \& Galamba K.R. 2016. Sustainability in facilities management: An overview of current research. Facilities, 34(9/10), pp. 535-563.

[52] Cadarso, M.A., Gómez, N., López, L.A. \& Tobarra, M.A. 2016. Calculating tourism's carbon footprint: Measuring the impact of investments. Journal of Cleaner Production, 111B, pp. 529-537.

[53] Singal, M. 2014. The link between firm financial performance and investment in sustainability initiative. Cornell Hospitality Quarterly, 55(1), pp. 19-30.

[54] García-Pozo, A., Sánchez-Ollero, J.L. \& Marchante-Mera, A. 2013. Environmental sustainability measures and their impacts on hotel room pricing in Andalusia (Southern Spain). Environmental Engineering and Management Journal, 12(10), pp. 1971-1978.

[55] Jones, P., Hillier, D. \& Comfort, D. 2014. Sustainability in the global hotel industry. International Journal of Contemporary Hospitality Management, 26(1), pp. 5-17. 
[56] Lai, J.H.K. 2014. Mandatory reporting of greenhouse gas emissions from buildings: Stakeholders' opinions in Hong Kong. Energy Policy, 75, pp. 278-288.

[57] Roper, J. 2012. Environmental risk, sustainability discourses and public relations. Public Relations Inquiry, 1(1), pp. 69-87.

[58] Leslie, D. 2008. From strategic planning to strategy implementation in the hotel industry in South Africa. Pretoria: University of Pretoria, Faculty of Economic and Management Sciences, Department of Tourism Management.

[59] Mutindi, U.J.M., Namusonge, G.S.N. \& and Obwogi, J. 2013. Effects of strategic management drivers on organisation performance: A survey of the hotel industry in Kenyan coast. International Journal of Arts and Commerce, 2(11), pp. 83-105.

[60] Wang C.-H., Chen, K.-Y. \& Chen, S.-C. 2012. Total quality management, market orientation and hotel performance: The moderating effects of external environmental factors. International Journal of Hospitality Management, 31, pp. 119-129.

[61] Phillips, P. \& Louvieris, P. 2008. Performance measurement systems in tourism, hospitality, and leisure small medium-sized enterprises: A balanced scorecard perspective. Journal of Travel Research, 44, p.201.

[62] Dash, S. \& Mahapatra, J. 2016. Strategies for sustaining competitive advantages in hotel industries of India: A case study of selected hotels. International Journal of Advancement, in Engineering Technology, Management and Applied Science (IJAETMAS), 3(12), pp. 67-88.

[63] Mutheu, M.C. 2013. Competitive strategies adopted by Tribe Hotel in Nairobi, Kenya. Nairobi: University of Nairobi, School of Business.

[64] Yilmaz, Y. 2013. Impact of strategy on efficiency in the luxury hotel industry of Turkey. Anatolia: An International Journal of Tourism and Hospitality Research, 24(2), pp. 206-220.

[65] Daghfous, A. \& Barkhi, R. 2009. The strategic management of information technology, in UAE hotels: An exploratory study of TQM, SCM, and CRM implementation. Technovation, 29, pp. 588-595.

[66] Scholz, P. \& Voracek, J. 2016. Organizational culture and green management: Innovative way ahead in hotel industry. Measuring Business Excellence, 20(1), pp. 41-52.

[67] Lacagnina, V. \& Provenzano, D. 2009. An optimized system dynamics approach for a hotel chain management, in Matias Á., Nijkamp P., Sarmento M. (eds) Advances in Tourism Economics. Physica-Verlag HD. pp. 35-49.

[68] Georgantzas, N.C. 2003. Tourism dynamics: Cyprus' hotel value chain and profitability. System Dynamics Review, 19(3), pp. 175-212.

[69] Pizzitutti, F., Walsh, S.J., Rindfuss, R.R., Gunter, R., Quiroga, D., Tippett, R. \& Mena, C.F. 2016. Scenario planning for tourism management: A participatory and system dynamics model applied to the Galapagos Islands of Ecuador. Journal of Sustainable Tourism, 25(8), pp. 1117-1137.

[70] Anctil, A. \& Le Blanc, D. 2016. An educational simulation tool for integrated coastal tourism development in developing countries. Journal of Sustainable Tourism, 24(5), pp. 783-798.

[71] Law, A., De Lacy, T., McGrath, G.M., Whitelaw, P.A., Lipman, G. \& Buckley G. 2012. Towards a green economy decision support system for tourism destinations. Journal of Sustainable Tourism, 20(6), pp.823843.

[72] Thanh, M. \& Smith, C. 2015. Addressing the threats to tourism sustainability using systems thinking: A case study of Cat Ba Island, Vietnam. Journal of Sustainable Tourism, 23(10), pp. 1504-1528.

[73] Nguyen, N.C. \& Bosch, O.J.H. 2012. A systems thinking approach to identify leverage points for sustainability: A case study in the Cat Ba biosphere reserve, Vietnam. Systems Research and Behavioral Science, 30, pp. 104-115.

[74] Thanh, V.M., Bosch, O.J.H. \& Maani, E.K. 2011. Towards a shared systems model of stakeholders in tourism development in the Cat Ba biosphere reserve of Vietnam. 29th International Conference of the System Dynamics Society, 24-28 July 2011. Washington, DC: System Dynamics Society.

[75] Nguyen, N.C., Graham, D., Ross, H., Maani, E.K. \& Bosch, O.J.H. 2011. Educating systems thinking for sustainability: Experience with a developing country. Systems Research and Behavioral Science, 29(1), pp. 14-29.

[76] Thanh, V.M. \& Bosch, O.J.H. 2010. Systems thinking approach as a unique tool for sustainable tourism development: A case study in the CAT BA biosphere reserve of Vietnam. 54th Annual Conference of the International Society for the Systems Sciences (ISSS) 2010: Governance for a Resilient Planet, 18-23 July 2010. Waterloo, Canada: ISSS.

[77] Thanh, V.M. \& Maani, E.K. 2010. Systems thinking for sustainable tourism in the Cat Ba biosphere reserve of Vietnam. Proceedings of Regional Conference on Tourism Research: The State of the Art and its Sustainability. 13-14 December 2010. Penang, Malaysia: Universiti Sains Malaysia, pp. 26-35. 